\title{
Bakti Sosial Jantung Sehat: Pengembangan Upaya Preventif Kardiovaskuler dan Peningkatan Kualitas Hidup Lansia
}

\author{
Yanna Indrayana*1, Herpan Syafii Harahap ${ }^{2}$, Dion Setiawan ${ }^{3}$, Amanda Halimi ${ }^{4}$ \\ ${ }^{1}$ Departemen Kardiologi, Fakultas Kedokteran Universitas Mataram, Mataram, Indonesia \\ ${ }^{2}$ Departemen Neurologi, Fakultas Kedokteran Universitas Mataram, Mataram, Indonesia \\ ${ }^{3}$ Rumah Sakit Umum Daerah Kabupaten Lombok Utara, Lombok Utara, Indonesia \\ ${ }^{4}$ Rumah Sakit Umum Daerah Provinsi Nusa Tenggara Barat, Mataram, Indonesia
}

\section{Article history}

Received: 23 November 2019

Revised: 28 Januari 2020

Accepted: 01 Maret 2020

*Corresponding Author:

Yanna Indrayana,

Departemen Kardiologi,

Fakulats Kedokteran

Universitas Mataram, Mataram,

Indonesia;

Email:

yannaindrayana@unram.ac.id
Abstract: Cardiovascular disease is the major causes of death in the world. Hypertension and diabetes mellitus are the important risk factors for cardiovascular disease. The prevalence of hypertension and diabetes mellitus is higher in the elderly population. Promotive and preventive efforts for the occurrence of hypertension and diabetes mellitus are the important strategies for preventing cardiovascular disease in elderly population. This was a social activity program developingthe preventive strategy against cardiovascular disease and improving of the quality of life of the elderly. This activity program was attended by 66 elderly participants routinely participated in the Panti Sosial Tresna Werdha Puspa Karma, Mataram. This program were consisted of counseling and healthy heart gymnasticsregularly every week for 3 months. The parameters taken in this event are height, body mass index (BMI), abdominal circumference, systolic and diastolic blood pressure, and serum fasting blood glucose (GDP) levels at the beginning and end of the programin order to assess the success of this program in reducingthe risk of suffered from cardiovascular disease. There were significant differences in the mean of body weight, BMI, abdominal circumference, systolic and diastolic blood pressure, and serum GDP levels between the the beginning and end of the programs $(p<0.05)$. This social activity program reduced effectively the risk of cardiovascular disease in the elderly.

Keywords: Cardiovascular disease; hypertension; diabetes; elderly

Abtrak: Penyakit kardiovaskuler merupakan salah satu penyakit penyebab angka kematian yang tertinggi di dunia. Hipertensi dan diabetes melitus merupakan faktor risiko penting untuk terjadinya penyakit kardiovaskuler. Prevalensi hipertensi dan diabetes melitus lebih tinggi pada populasi lanjut usia. Upaya promotif dan preventif untuk terjadinya penyakit hipertensi dan diabetes melitus merupakan strategi penting untuk mencegah terjadinya penyakit kardiovaskuler pada populasi lanjut usia. Kegiatan pengabdian ini merupakan pengembangan upaya preventif terhadap penyakit kardiovaskuler dan peningkatan kualitas hidup lanjut usia. Kegiatan ini diikuti oleh 66 orang peserta lanjut usia yang rutin mengikuti kegiatan di Panti Sosial Tresna Werdha Puspa Karma Mataram. Upaya pengembangan yang dilakukan adalah dengan kegiatan penyuluhan dan senam jantung sehat setiap minggu selama 3 bulan. Pada kegiatan ini, dilakukan pengukuran terhadap tinggi badan, indeks massa tubuh (IMT), lingkar perut, tekanan darah sistolik dan diastolik, dan kadar glukosa darah puasa (GDP) serum pada awal dan akhir kegiatan untuk menilai keberhasilan upaya penurunan risiko terjadinya penyakit 
kardiovaskuler. Terdapat perbedaan rerata yang bermakna dalam hal berat badan, IMT, lingkar perut, tekanan darah sistolik dan diastolik, dan kadar GDP serum antara hasil pemeriksaan awal dan akhir kegiatan $(\mathrm{p}<0.05)$. Hal ini menunjukkan bahwa kegiatan pengabdian ini mampu menurunkan risiko terjadinya penyakit kardiovaskuler para lansia.

Kata Kunci: Penyakit kardiovaskuler; hipertensi; diabetes melitus; lanjut usia

\section{PENDAHULUAN}

Penyakit jantung merupakan salah satu penyakit penyebab angka kematian yang tertinggi di dunia. Sebesar $48 \%$ kematian di dunia yang disebabkan oleh penyakit kardiovaskular (World Health Organization, 2008). Penyakit jantung koroner (PJK) merupakan penyakit jantung terbanyak yang menyebabkan kematian di Amerika (Central for Disease Control and Prevention, 2014). Di Inggris, penyakit jantung merupakan penyebab kematian yang tertinggi, sekitar 82.000 dikarenakan PJK (Haffner et al., 1998). Di Indonesia, angka kematian yang disebabkan oleh PJK mencapai $26 \%$. Prevalensi PJK di Indonesia tahun 2013 berdasarkan diagnosis dokter sebesar 0.5\% (Badan Penelitian dan Pengembangan Kesehatan, 2013).

Riset Kesehatan Dasar atau Riskesdas 2007, menunjukkan bahwa prevalensi penyakit jantung secara nasional adalah $7.2 \%$ dan penyakit jantung iskemik mempunyai proporsi sebesar $5.1 \%$ dari seluruh penyakit penyebab kematian di Indonesia. Hasil penelitian kohort di Pusat Jantung Nasional Harapan Kita dan 5 rumah sakit di Indonesia di tahun 2006 menunjukkan bahwa angka kematian karena penyakit jantung dan pembuluh darah di rumah sakit adalah sekitar 6-12\% dan angka rehospitalisasi yaitu 29\% (Badan Penelitian dan Pengembangan Kesehatan, 2007).

Beberapa faktor risiko penting untuk terjadinya penyakit kardiovaskuler adalah hipertensi dan diabetes melitus. Hipertensi merupakan masalah kesehatan yang serius dan penting (Siyad, 2011). Berdasarkan data World Heart Organization (WHO), 40\% dari populasi yang berusia lebih dari 25 tahun menderita hipertensi (Kishore et al., 2016). Prevalensi hipertensi di Indonesia mencapai 31.7\% namun hanya $7.6 \%$ yang menerima pengobatan antihipertensi. Hipertensi tidak terkontrol merupakan faktor resiko kejadian penyakit kardiovaskuler dan serebrovaskuler (Kearney et al., 2005; Kishore et al., 2016).Prevalensi hipertensi meningkat dengan bertambahnya usia; misalnya, sekitar $50 \%$ dari orang antara usia 60 dan 69 tahun memiliki hipertensi, dan prevalensi ini lebih meningkat setelah usia 70 tahun (Iqbal, 2011).

Diabetes melitus juga merupakan salah satu faktor risiko untuk terjadinya penyakit kardiovaskuler, baik secara independen maupun melalui interaksinya dengan faktor-faktor risiko penyakit kardiovaskuler lainnya, termasuk hipertensi (Martin-Timon et al., 2014). Penelitian yang dikerjakan oleh Wong et al. menunjukkan bahwa kontrol kadar glukosa darah dan tekanan darah secara optimal mampu menurunkan risiko penyakit kardiovaskuler (Leon and Maddox, 2015; Wong et al., 2016). Suatu telaah sistematik menunjukkan bahwa setengah total jumlah pasien diabetes melitus tipe 2 mengalami kematian akibat penyakit kardiovaskuler (Einarson et al., 2018). Prevalensi penyakit diabetes melitus di Indonesia saat ini diperkirakan sebesar 5.7\% (Badan Penelitian dan Pengembangan Kesehatan, 2007; Soewondo et al., 2013). Dengan melihat tingginya angka kejadian penyakit diabetes melitus dan fakta bahwa diabetes melitus merupakan faktor risiko penting untuk terjadinya penyakit kardiovaskuler, maka upaya promotif dan preventif untuk terjadinya penyakit diabetes melitus juga merupakan strategi penting untuk mencegah terjadinya penyakit kardiovaskuler. 
Pada pasien dengan penyakit kardiovaskular maupun kelompok usia lanjut usia (lansia), aktivitas fisik terbukti dapat meningkatkan kualitas hidup dengan cara mengurangi stres, meningkatkan antusiasme dan percaya diri, mengurangi kecemasan dan depresi berkaitan dengan penyakit yang diderita. Hal ini telah dibuktikan dengan peningkatan kualitas hidup pada penderita hipertensi di beberapa penelitian. Kelompok penderita yang melakukan aktivitas tinggi memiliki skor kualitas hidup yang lebih tinggi dibandingkan dengan yang melakukan aktivitas rendah (Setiawan et al., 2013). Suatu penelitian menunjukkan bahwa kelompok yang berolahraga mengalami perbaikan pada kesehatan secara umum, terutama penurunan tekanan darah sistolik (Tsai et al., 2004). Tujuan dari kegiatan pengabdian masyarakat ini adalah untuk mengetahui pengaruh kegiatan penyuluhan dan senam jantung sehat setiap minggu selama 3 bulan pada populasi lanjut usia terhadap keberhasilan dalam upaya penurunan risiko terjadinya penyakit kardiovaskuler.

\section{METODE}

Kegiatan bakti sosial dilaksanakan selama 3 bulan di Panti Sosial Tresna Werdha Puspa Karma, Kota Mataram. Kegiatan bakti sosial ini memiliki 4 tahapan kegiatan, antara lain pemeriksaan fisik awal, senam jantung sehat, penyuluhan kesehatan, pemeriksaan fisik akhir. Pada tahap pemeriksaan fisik awal, peserta akan menjalani pemeriksaan antropometri (tinggi badan, berat badan, Indeks Massa Tubuh (IMT) dan lingkar perut), dan tekanan darah di setiap sesi senam jantung sehat.

Pada tahap kedua, senam jantung sehat akan dilakukan 3 kali seminggu berdurasi 60 menit selama 3 bulan yang dilaksanakan setiap hari Selasa, Kamis, dan Sabtu pada pukul 07.00 WITA dengan dipandu oleh 1 orang instruktur senam dari Yayasan Jantung Sehat. Setiap sesi senam dilaksanakan selama kurang lebih selama 1 jam. Perlu diketahui bahwa kegiatan senam ini merupakan kegiatan rutin yang dilaksanakan di Panti Sosial Tresna Werdha Puspa Karma. Untuk menunjang kegiatan tersebut, tim pengabdian masyarakat akan menyediakan air mineral untuk 100 orang peserta di tiap sesinya dan melakukan pemeriksaan fisik sebelum dilakukan senam.

Pada tahap ketiga, peserta juga akan diberikan penyuluhan kesehatan mengenai beberapa faktor risiko untuk terjadinya penyakit kardiovaskuler yang perlu diketahui, antara lain obesitas, hipertensi, diabetes mellitus tipe 2, dan merokok. Pada kegiatan penyuluhan tersebut, peserta juga diedukasi mengenai bagaimana cara mencegah terjadinya faktor-faktor risiko tersebut atau mencegah komplikasinya, bila sudah memiliki faktor-faktor risiko tersebut, melalui pengaturan asupan nutrisi yang seimbang secara rutin. Penyuluhan kesehatan ini dilakukan setiap hari selasa, yaitu sebanyak 12 kali dan materi penyuluhan disampaikan oleh 2 orang dokter yang berkompeten di bidangnya.

Pada tahap keempat, dilakukan pemeriksaan fisik akhir dengan cara yang sama seperti pada tahap pertama. Tujuan pemeriksaan fisik dan penilaian kualitas hidup pada akhir kegiatan ini bertujuan untuk mengevaluasi keberhasilan program kegiatan bakti sosial ini. Hasil pemeriksaan fisik pada awal dan akhir kegiatan dianalisis secara statistik untuk mengetahui adanya perbedaan rerata yang signifikan dari beberapa parameter pemeriksaan fisik tersebut, yaitu berat badan, IMT, lingkar perut, tekanan darah sistolik dan diastolik, dan kadar glukosa darah puasa antara hasil pemeriksaan awal dan akhir. Uji statistik yang digunakan untuk menilai uji beda parameter-parameter tersebut adalah uji non-parametrik Wilcoxon. Hasil uji statistik bermakna jika didapatkan nilai $\mathrm{p}<0.05$. 


\section{HASIL DAN PEMBAHASAN}

Kegiatan pengabdian masyarakat dengan tema "Bakti Sosial Jantung Sehat: Pengembangan Upaya Preventif Kardiovaskuler dan Peningkatan Kualitas Hidup Lansia" ini diikuti oleh 66 orang peserta lansia. Dalam kegiatan tersebut, para peserta menunjukkan antusiasmenya dalam mengikuti seluruh rangkaian kegiatan yang berlangsung selama 3 bulan tersebut, baik dalam kegiatan pemeriksaan fisik, penyuluhan, maupun senam jantung sehat (Gambar 1).
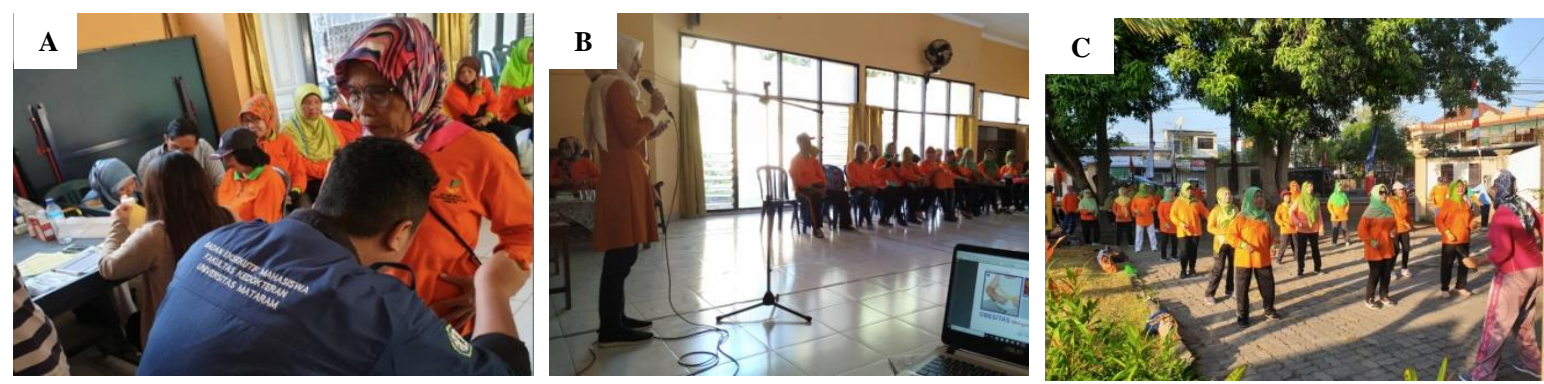

Gambar Pelaksanaan kegiatan pengabdian kepada masyarakat dengan tema pengembangan upaya preventif kardiovaskuler dan peningkatan kualitas hidup lanjut usia
A. Kegiatan pemeriksaan fisik pada lanjut usia
B. Kegiatan penyuluhan dengan topik obesitas, hipertensi, bahaya rokok, dan diabetes melitus
C. Kegiatan senam jantung sehat

Dari total 66 peserta lansia, dilakukan pengambilan karakteristik demografik (usia, jenis kelamin, dan tingkat pendidikan) dan klinik (riwayat penyakit hipertensi dan diabetes melitus). Hasil selengkapnya disajikan pada Tabel 1 .

Tabel 1. Karakteristik demografik dan klinik peserta kegiatan

\begin{tabular}{llr}
\hline \multicolumn{1}{c}{ Kategori } & \multicolumn{1}{c}{ Sub-kategori } & Jumlah \\
\hline Usia dalam tahun (rerata \pm SD*) & & $66.4 \pm 3.8$ \\
Jenis kelamin, n (\%) & Laki-laki & $11(16.7)$ \\
& Perempuan & $55(83.3)$ \\
Tingkat pendidikan, n (\%) & SD** & $12(18.2)$ \\
& SMP & $25(37.9)$ \\
& SMA & $18(27.3)$ \\
Hipertensi, n (\%) & Sarjana & $11(16.7)$ \\
& Ya & $12(18.2)$ \\
Diabetes melitus, n $(\%)$ & Tidak & $54(81.8)$ \\
& Ya & $18(27.3)$ \\
SD*=standar deviasi; $\quad$ SD**=sekolah dasar; SMP=sekolah & menengah \\
pertama; SMA=sekolah menengah atas & &
\end{tabular}

Pada Tabel 1 dapat dilihat bahwa peserta kegiatan ini merupakan lansia dengan rerata usia 66 tahun. Sebagian besar peserta berjenis kelamin perempuan (83.3\%) dan memiliki tingkat pendidikan 
SMP (37.9\%). Proporsi peserta yang memiliki riwayat penyakit hipertensi dan diabetes melitus masing-masing sebesar $18.2 \%$ dan $27.3 \%$. Upaya promotif dan preventif yang dilakukan dalam kegiatan ini sangat penting untuk dilakukan untuk seluruh peserta, baik yang belum maupun yang sudah memiliki faktor risiko penyakit kardiovaskuler, dalam hal ini adalah penyakit hipertensi dan diabetes melitus. Untuk para peserta yang belum memiliki faktor risiko penyakit kardiovaskuler, yaitu yang belum memiliki penyakit hipertensi dan diabetes melitus, maka upaya promotif dan preventif yang dilakukan dalam kegiatan ini adalah supaya mereka tidak menderita penyakit hipertensi dan diabetes melitus. Bagi para peserta yang sudah memiliki penyakit hipertensi dan/atau diabetes melitus, upaya promotif dan preventif dalam kegiatan ini bertujuan untuk menghindarkan mereka dari kejadian penyakit kardiovaskuler.

Upaya promotif dan preventif yang dilakukan pada kegiatan ini meliputi empat fase kegiatan, antara lain pemeriksaan fisik awal, senam jantung sehat, penyuluhan kesehatan, dan pemeriksaan fisik akhir. Pemeriksaan fisik yang dilakukan dalam kegiatan ini meliputi parameter pengukuran berat badan, IMT, lingkar perut, tekanan darah sistolik dan diastolik, dan kadar glukosa darah puasa serum. Parameter-parameter tersebut sangat penting dalam penilaian risiko terjadinya penyakit kardiovaskuler. Pemeriksaan fisik tersebut dilakukan di awal dan akhir kegiatan untuk kemudian dievaluasi apakah intervensi yang diberikan berupa penyuluhan dan senam sehat secara rutin sebanyak 12 kali dalam kurun waktu 3 bulan memberikan perbedaan bermakna terhadap parameter-parameter pemeriksaan fisik tersebut antara awal dan akhir kegiatan. Berikut ini disajikan hasil pemeriksaan fisik awal dan akhir dalam kegiatan ini, sekaligus hasil analisis statistiknya (Tabel 2).

Tabel 2. Hasil pemeriksaan fisik awal dan akhir kegiatan pengabdian

\begin{tabular}{lccc}
\hline \multicolumn{1}{c}{ Parameter } & \multicolumn{2}{c}{ Pemeriksaan Fisik (rerata \pm SD) } & \multirow{2}{*}{ Nilai p } \\
\cline { 2 - 3 } & Awal $(\mathbf{n}=66)$ & Akhir $(\mathbf{n}=66)$ & \\
\hline Berat badan dalam kg & $60.9 \pm 9.03$ & $60.1 \pm 8.35$ & 0.001 \\
IMT dalam kg/m² & $25.6 \pm 3.35$ & $25.3 \pm 3.11$ & 0.001 \\
Lingkar perut dalam cm & $81.2 \pm 8.96$ & $80.3 \pm 8.37$ & 0.000 \\
Tekanan darah sistolik dalam mmHg & $134.2 \pm 22.79$ & $125.0 \pm 17.12$ & 0.000 \\
Tekanan darah diastolik dalam mmHg & $83.2 \pm 10.93$ & $79.9 \pm 9.32$ & 0.007 \\
Glukosa darah puasa dalam mg/dl & $121.0 \pm 32.66$ & $113.4 \pm 35.22$ & 0.000 \\
\hline
\end{tabular}

Uji statistik Wilcoxon, bermakna bila $\mathrm{p}<0.05$

IMT=indeks massa tubuh

Pada tabel diatas dapat dilihat bahwa, terdapat perbedaan bermakna pada rerata hasil pemeriksaan parameter berat badan, IMT, lingkar perut, tekanan darah sistolik dan diastolik, dan kadar glukosa darah puasa para peserta antara pemeriksaan awal dan akhir $(\mathrm{p}<0.05)$. Berat badan dan lingkar perut merupakan parameter penting untuk penilaian adanya obesitas dan obesitas sentral (Kurniawati, 2018). Nilai IMT (diperoleh dari hasil bagi berat badan dalam kilogram oleh kuadrat tinggi badan dalam meter persegi) dan lingkar perut diatas nilai normal menunjukkan bahwa individu tersebut memiliki faktor risiko untuk terjadinya resistensi insulin, suatu proses yang mendasari terjadinya diabetes melitus tipe 2 (Leon and Maddox, 2015). Dengan demikian, intervensi terhadap 
berat badan, IMT, dan lingkar perut akan menurunkan risiko seseorang untuk berkembang menjadi diabetes melitus. Pada kegiatan pengabdian ini, perbedaan yang bermakna dalam hal rerata berat badan, IMT, dan lingkar perut antara awal dan akhir pelaksanaan kegiatan pengabdian menunjukkan bahwa upaya promosi dan preventif (penyuluhan dan senam teratur selama 3 bulan) mampu menurunkan risiko peserta untuk menderita penyakit diabetes melitus dan penyakit kardiovaskuler.

Hipertensi menurut JNC 7 didefinisikan sebagai kondisi klinis yang ditandai dengan hasil pemeriksaan tekanan darah sistolik $\geq 140 \mathrm{mmHg}$ dan/atau diastolik $\geq 90 \mathrm{mmHg}$ (National Heart, Lung, and Blood Institute, 2003). Pada kegiatan pengabdian ini, rerata tekanan darah sistolik dan diastolik pada akhir kegiatan pengabdian secara bermakna lebih rendah dibandingkan dengan reratanya pada awal kegiatan pengabdian. Hasil tersebut menunjukkan bahwa upaya promotif dan preventif yang dilakukan pada kegiatan pengabdian ini juga mampu memberikan kontrol yang optimal terhadap tekanan darah peserta kegiatan, dengan demikian juga menurunkan risiko terjadinya penyakit kardiovaskuler.

\section{KESIMPULAN DAN SARAN}

Dengan melihat besarnya manfaat kegiatan pengabdian ini terhadap upaya penurunan tingkat risiko penyakit kardiovaskuler pada kelompok lansia di Panti Sosial Tresna Werdha Puspa Karma ini, maka perlu diupayakan agar kegiatan promotif dan preventif yang sudah diinisiasi tersebut tetap terus dilanjutkan. Kegiatan serupa juga perlu dilaksanakan di populasi lansia lainnya yang ada di Kota Mataram. Perlu dilakukan evaluasi pelaksanaan kegiatan tersebut secara berkala mengenai dampaknya terhadap derajat kesehatan dari peserta kegiatan.

\section{Ucapan Terima Kasih}

Penulis mengucapkan terima kasih Lembaga Penelitian dan Pengabdian kepada Masyarakat (LPPM) Universitas Mataram yang telah memberikan dukungan dana pada kegiatan ini melalui dana DIPA BLU Universitas Mataram Tahun Anggaran 2019. Penulis juga mengucapkan terima kasih kepada pihak Panti Sosial Tresna Werdha Puspa Karma Mataram yang telah memberikan ijin dan memfasilitasi pelaksanaan kegiatan pengabdian ini

\section{DAFTAR PUSTAKA}

Badan Penelitian dan Pengembangan Kesehatan. Riset Kesehatan Dasar (RISKESDAS) 2007. Jakarta: Badan Penelitian dan Pengembangan Kesehatan Kementerian Kesehatan RI. 2007.

Badan Penelitian dan Pengembangan Kesehatan. Riset Kesehatan Dasar (RISKESDAS) 2013. Jakarta: Badan Penelitian dan Pengembangan Kesehatan Kementerian Kesehatan RI. 2013.

Central for Disease Control and Prevention. Diabetes in The United States. http://www.cdc.gov/diabetes/prevention. 2014.

Einarson TR, Acs A, Ludwig C, Panton UH. Prevalence of cardiovascular disease in type 2 diabetes: a systematic literature review of scientific evidence from across the world in 2007-2017. Cardiovascular Diabetology2018;17:83.

Haffner SM, Lehto S, Ronnemaa T, Pyorala K, Laakso M. Mortality from coronary heart disease in subjects with type 2 diabetes and in non-diabetic subjects with and without prior myocardial infarction. N Engl J Med 1998;339(4):229-234. 
Iqbal M. Clinical Perspective on The Management of Hypertension. Indian Journal of Clinical Medicine. 2011; 2:1-17.

Kearney PM, Whelton M, Reynolds K, Muntner P, Whelton PK, He J. Global burden of hypertension: analysis of worldwide data. Lancet 2005; 365 (9455):217-223.

Kishore J, Gupta N, Kohli C, Kumar N. Prevalence of Hypertension and Determination of Its Risk Factors in Rural Delhi. International Journal of Hypertension. 2016; 2016:7962595.

Kurniawati N. Obesity and Central obesity. Med J Indones 2018; 27 (2):69-70.

Leon BM, Maddox TM. Diabetes and cardiovascular disease: Epidemiology, biological mechanisms, treatment recommendations and future research. World J Diabetes 2015; 6 (13):1246-1258.

Martin-Timon I, Sevillano-Collantes C, Segura-Galindo A, del Canizo-Gomez FJ. Type 2 diabetes and cardiovascular disease: Have all risk factors the same strength? World J Diabetes 2014; 5(4):444-470.

National Heart, Lung, and Blood Institute. The Seventh Report of the Joint National Committee on Prevention, Detection, Evaluation, andTreatment of High Blood Pressure. USA: NIH Publication. 2004.

Setiawan GW, Wungouw HIS, Pangemanan DHC. Pengaruh senam bugar lanjut usia (lansia) terhadap kualitas hidup penderita hipertensi. Jurnal e-Biomedik 2013; 1 (2): 760-764.

Siyad AR. Hypertension. Hygeia J D Med 2011; 3(1):1-16.

Soewondo P, Ferrario A, Tahapary DL. Challenges in diabetes management in Indonesia: a literature review. Globalization and Health 2013; 9:63.

Tsai JC, Yang HY, Wang WH, et al. The beneficial effect of regular endurance exercise training on blood pressure and quality of life in patients with hypertension. Clinical and Experimental Hypertension 2004; 26 (3): 255-265.

Wong ND, Zhao Y, Patel R, et al. Cardiovascular Risk FactorTargets and CardiovascularDisease Event Risk in Diabetes:A Pooling Project of theAtherosclerosis Risk inCommunities Study, Multi-EthnicStudy of Atherosclerosis, andJackson Heart Study. Diabetes Care2016; 39:668676.

World Health Organization. The top ten causes of death. Diakses dari: http://www.who.int/mediacentre/factsheets/fs310_2008. 2008 